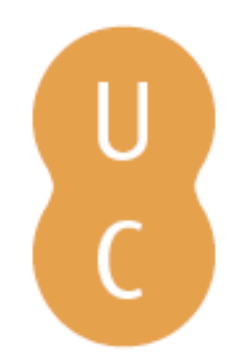

\title{
pommalina
}

\section{O estrangeiro na comédia grega antiga}
Autor(es):
Silva, Maria de Fátima
Publicado por: Imprensa da Universidade de Coimbra
URL persistente:
URI:http://hdl.handle.net/10316.2/32395
DOI:
DOI:http://dx.doi.org/10.14195/978-989-26-0393-3_8

Accessed : $\quad$ 26-Apr-2023 16:34:39

A navegação consulta e descarregamento dos títulos inseridos nas Bibliotecas Digitais UC Digitalis, UC Pombalina e UC Impactum, pressupõem a aceitação plena e sem reservas dos Termos e Condições de Uso destas Bibliotecas Digitais, disponíveis em https://digitalis.uc.pt/pt-pt/termos.

Conforme exposto nos referidos Termos e Condições de Uso, o descarregamento de títulos de acesso restrito requer uma licença válida de autorização devendo o utilizador aceder ao(s) documento(s) a partir de um endereço de IP da instituição detentora da supramencionada licença.

Ao utilizador é apenas permitido o descarregamento para uso pessoal, pelo que o emprego do(s) título(s) descarregado(s) para outro fim, designadamente comercial, carece de autorização do respetivo autor ou editor da obra.

Na medida em que todas as obras da UC Digitalis se encontram protegidas pelo Código do Direito de Autor e Direitos Conexos e demais legislação aplicável, toda a cópia, parcial ou total, deste documento, nos casos em que é legalmente admitida, deverá conter ou fazer-se acompanhar por este aviso.

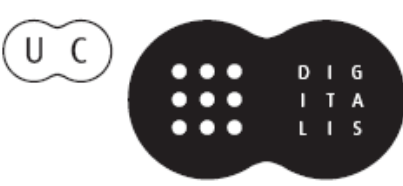




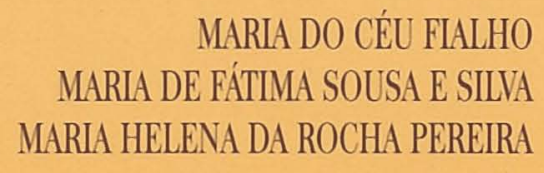

Coordenação

\section{Génese e consolidaç̃ão da ideia de Europa} Vol. I: de Homero ao fim da época clássica 
MARIA DO CÉU FIALHO

MARIA DE FÁTIMA SOUSA E SILVA

MARIA HELENA DA ROCHA PEREIRA

Coordenação

\section{Génese e consolidação da ideia de Europa}

Vol. I: de Homero an fim da época clíssica 


\title{
Coordenação editorial
}

Imprensa da Universidade de Coimbra

\section{Concepção gráfica}

António Barros

\section{Paginação}

Victor Hugo Fernandes

\section{Execução gráfica}

SerSilito - Maia

\section{ISBN}

972-8704-57-7

\section{Depósito Legal}

234088/05

(C) Outubro 2005, Imprensa da Universidade de Coimbra

\author{
Obra PUblicada COM O FINANCIAMENTO DE:
}

Centro de Estudos Clássicos e Humanísticos

$$
\text { FCT Fundaçāo para a Ciência e a Tecnologia }
$$

OBRA PUBLICADA COM O APOIO DE:

FCT: Fundação para a Ciência e Tecnologia - Ministério da Ciência e do Ensino Superior Apoio do Programa Operacional para a Ciência, Tecnologia, Inovação do III Quadro Comunitário de Apoio 



\title{
O estrangeiro na COMÉdia grega Antiga ${ }^{(1)}$
}

\author{
Maria de Fátima Silva \\ (Universidade de Coimbra)
}

A figura do estrangeiro impõe-se no teatro grego - tragédia e comédia - desde cedo e conquista um espaço de grande dimensão. É, antes de mais, o mito, permeado de motivos de origem não helénica, que infiltra, com maior relevo na tragédia, essa componente ${ }^{(2)}$. Mas o fluir histórico havia de encarregar-se, pelos conflitos e contactos cada vez mais assíduos entre os povos, bem como pelo conhecimento mútuo sempre mais amplo, de a alimentar e enriquecer. Daqui resultou que o séc. V a. C. possuiu uma consciência clara sobre uma outra realidade cultural, que estabelecia uma fronteira entre Gregos e o que genericamente se designava por Bárbaros. À luz desse conhecimento estabeleceu contrastes de cultura entre a sua identidade e o outro, e pôde mesmo reler, em nova perspectiva, os dados do mito. Para poetas dramáticos mais em evidência, as descrições etnográficas dos geógrafos e historiadores converteram-se num manancial inesgotável de curiosidades. E se considerarmos, para além dos aspectos culturais e históricos, apenas questões técnicas da cena, não custa a crer que as potencialidades dramáticas deste motivo fossem também um estímulo permanente para o seu uso no teatro.

(1) As citações de Aristófanes são feitas pela edição de V. Coulon et H. Van Daele, Aristophane, I-V (Paris, reimpr. 1967-1972). As dos fragmentos de comédia por Kassel-Austin, Poetae comici graeci, Berlim, 1983-1989.

(2) Sobre a presença do estrangeiro na tragédia, vide $\mathrm{H}$. H. Bacon, Barbarians in tragedy (New Haven, 1961); E. Hall, Inventing the barbarian. Greek self definition through tragedy (Oxford, 1989). 
Ainda que menos dependente do mito do que a tragédia, a comédia acolhe, por vias diversas, a personagem do estrangeiro. É difícil estabelecer-lhe um marco cronológico, mas talvez não seja muito arrojada a hipótese emitida por Pickard-Cambridge ${ }^{(3)}$ 'de que estes mascarados <os que compunham os komoi> se não limitassem a usar disfarces animalescos, mas que tivessem também representado, por exemplo, estrangeiros, tal como as crianças hoje em dia se vestem de peles vermelhas'. No mesmo sentido, Ateneu (14. 621 sq.), ao comentar a existência de farsas primitivas entre os Dórios em data tão recuada quanto o séc. VI a. C., de natureza eminentemente espontânea e popular, refere a imitação do médico estrangeiro que fala uma estranha linguagem. E toda a polémica discussão sobre as origens da comédia tem sido unânime em aceitar a importância destes modelos fornecidos pela farsa dórica para o surgir de uma verdadeira arte cómica na Ática; em toda a sua espontaneidade, a farsa testara e demonstrara as potencialidades humorísticas de recursos rudimentares, como certas figuras, atitudes e situações. Com o tempo, à medida que a comédia grega deixou de ser uma mera manifestação popular para se tornar uma verdadeira arte literária, essa tradição manteve-se viva e frutuosa. A ela associou-se a influência paralela da tragédia, de que a arte cómica se tornou discípula atenta e crítica irreverente, além do impulso decisivo da história do Mediterrâneo oriental.

Assim, para o Grego desta época era nítida a noção de um mundo envolvente, cuja existência e práticas o definiam como objectivamente não grego. Avultam nele os Persas, Lídios, Frígios, Mísios, Tauros na fronteira asiática, Egípcios na costa sul, Trácios e Ilírios na periferia balcânica. Acresce-lhes uma faixa de natureza ambígua, onde se integra a Macedónia e algumas regiões insulares, alternadamente sentidas como mais ou menos próximas da Hélade.

Ao incorporar o motivo do estrangeiro, o drama grego foi determinando uma técnica de tratamento e de caracterização, que pode ir da simples sugestão de um efeito exótico difuso e genérico, até à exploração minuciosa e precisa de uma personagem concreta e do espaço da sua proveniência. $\mathrm{O}$ aproveitamento de pormenores, como hábitos e costumes, o trajo, o aspecto físico e a linguagem, permite a definição de contrastes entre povos diversos e de todos eles com o seu referente natural e invariável: a comunidade helénica. Determina-se assim, progressivamente, um conjunto

(3) Dithyramb, tragedy and comedy, ed. revised by T. B. L. Webster (Oxford, 1962), 157. 
de traços convencionais, mais ou menos permanentes, que constituem a trama essencial do motivo. $\mathbf{E}$ para além das diferenças exteriores e objectivas, o teatro, na senda de uma tradição cultural, emite também juízos de valor, tendendo a encarecer uma certa inferioridade implícita no Bárbaro em relação ao Grego, ou pelo menos a discutir a falta de justificação para essa diferença, o que é uma outra maneira de a reconhecer e avaliar.

A figura do estrangeiro adquiriu, na comédia, a sua faceta própria. Desde sempre que o potencial ridículo da personagem parece ter valorizado, dos aspectos convencionais do teatro, alguns em particular: os costumes, o trajo e, sobretudo, a linguagem. Não é alheio ao quadro, no seu conjunto, um sabor depreciativo que faz daquele que se comporta de forma diferente e que não conhece a língua grega um tipo por excelência do estúpido e do abrutalhado. Delineava-se assim o perfil básico, popular e directo, do estrangeiro. Foi preciso depois enquadrá-lo, como tantos outros motivos da tradição, dentro de uma comédia 'política', didáctica, artística e fantasista. Dentro desse processo, o estrangeiro ganhou um sentido novo como componente da sátira política, literária ou social, numa perspectiva da caricatura 'realista' da actualidade contemporânea; sem deixar de proporcionar efeitos igualmente inestimáveis no plano mais ousado da ficção pura, quando à imaginação do poeta acode a criação de um espaço fantástico, como é o caso da geografia relativa de Nefelocucolândia e do Olimpo.

Já Quiónides, registado como o primeiro comediógrafo vencedor no festival das Dionísias, foi autor de uns Persas ou Assírios e o mesmo título de Persas, já antes aplicado na produção de Epicarmo, regressa com Ferécrates; por sua vez Metágenes é autor de uns Turiopersas e Teopompo de um Medo; Magnes de uns Lidios ${ }^{(4)}$; Cratino de umas Mulheres trácias ${ }^{(5)}$; Cálias de um Egípcio, bem como mais tarde Antífanes e Tímocles; ainda o mesmo Antífanes de uns Cários, Bizantinos e Lídio; Eubulo de uns Mísios; Nicóstrato de um Sírio; Estrátis de umas Fenícias; Tímocles e Xenarco de uns Citas; Ferécrates e Platão de uns Metecos; e, por último, Ferécrates

(4) Hesíquio glosa $\lambda v \delta i ́ \zeta \omega \nu$ como $\chi \circ \rho \in v ́ \omega \nu$, valorizando este elemento na comédia de Magnes.

(5) Cf. Estrabão 10. 3. 18: 'Os Atenienses são xenófilos em diversos aspectos, como por exemplo no referente aos deuses. Adoptaram muitos rituais estrangeiros a ponto de serem caricaturados. Estão neste caso os Trácios e os Frígios'. Note-se que também Ésquilo foi autor de umas Mulheres trácias. 
ainda de uns Selvagens ${ }^{(6)}$. Do conjunto sobressai a amplitude do motivo, já na comédia antiga, e a sua difusão cada vez em maior escala com o próprio caminhar evolutivo do género.

Voltemo-nos, em particular, para Aristófanes, como o autor que nos preserva exemplos concretos, circunscrevendo-nos aos casos em que a figura do estrangeiro se inspira na actualidade e em que tem uma verdadeira actuação dramática. Depois de uns Babilónios ${ }^{(7)}$, comédia voltada para a sátira da política ateniense encarnada em Cléon, é já em Acarnenses, a primeira peça conservada da produção de Aristófanes, que o modelo aparece e com alguma extensão. Trata-se, no prólogo, de parodiar uma sessão regular da assembleia do povo, onde Diceópolis pretende bater-se por um ponto fora da ordem do dia - a urgência de paz que sobretudo a população rural reclama - em detrimento daquela que é a substância da agenda prevista: a política externa de Atenas. Era este um campo recente de contactos entre a Grécia e os povos vizinhos. Dentro deste enquadramento, o conhecido tipo cómico enriquece-se de efeito, explorado numa linha progressiva. Primeiro, por um processo narrativo, traz-se à imaginação do público um universo e uma paisagem distantes, através da memória e experiência de testemunhos directos, os emissários de Atenas às cortes persa e trácia. Depois, esse mundo torna-se palpável, oferecendo-se à vista exemplares concretos, o Olho do Rei e o exército dos Odomantos. A comparação das duas cenas, que insistem genericamente no mesmo motivo, denuncia semelhanças convencionais, além de um manifesto esforço de variedade e renovação.

Um apelo do arauto ao silêncio ( $\sigma i$ ' $\alpha$, v. 64) marca a suspensão que antecede a entrada solene dos embaixadores; logo a exclamação empolada de Diceópolis estimula a vista e a imaginação. Depois da surpresa expressa no $\beta a \beta a \iota a ́ \xi$ (v. 64), somos atirados para o coração da Pérsia com uma exclamação à medida da circunstância, $\omega^{\prime} \kappa \beta a ́$ T $\alpha \nu \alpha^{(8)}$. Em vez do vulgar

(6) Cf. Platão, Protágoras 327c-d e a definição que dá de 'selvagem', reportando-se à comédia de Ferécrates como um paradigma: 'Aquele indivíduo que te parece intolerável numa comunidade formada no respeito da lei, esse mesmo pareceria um sujeito correcto e um mestre nessa matéria, se comparado com quem não conhece educação, nem justiça, nem lei, nem sente necessidade de se preocupar com a adopção de uma atitude correcta; numa palavra, gente selvagem do tipo daquela que o poeta Ferécrates apresentou nas Leneias do ano passado'.

(7) Tudo indica que o coro da peça era constituído por escravos babilónios. Videa informação dada por MacDowell, Aristophanes and Athens, 30.

${ }^{(8)}$ Sobre Ecbátana como terra de produção de trajos exóticos, cf. Ar., V. 1143-1149. 
nome de um deus, é a pátria distante do luxo que salta à imaginação do ateniense. Carregada de todas as conotações exóticas, logo um foco lhe ilumina um pormenor, o aspecto, e que aspecto (Tô̂ $\sigma \omega ́ \mu \alpha \tau o s)$ ! O trajo e a atitude impõem-se no aparato que os embaixadores importaram do distante El-Dorado. Tais são palavras suficientes para permitirem uma rubrica de cena: um embaixador avança com pompa e circunstância. Começa o relato da longa missão que agora chega ao fim: a Pérsia torna-se presente na imensidão das suas planícies, que os emissários levaram anos a percorrer, no conforto luxuoso do séquito diplomático (vv. 68-71). Enquadrada por dois lamentos - 'o que sofremos!', 'rebentámos de fadiga!' -, sobressai a imagem do luxo e requebro orientais: a protecção das tendas, o conforto dos $\operatorname{carros}^{(9)}$, a moleza das almofadas em que os viajantes se reclinam com

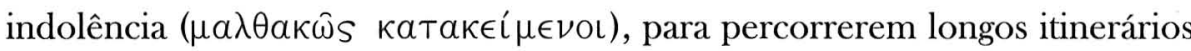
por uma rede viária cuja qualidade os Gregos bem conheciam.

Depois a pompa do acolhimento de que se viram rodeados, a riqueza do serviço e a abundância de manjares. Um simples $\xi \in \nu \iota \zeta o ́ \mu \in \nu o l$ (v. 73) 'éramos acolhidos' generaliza e indetermina os hospedeiros; e assim é a Pérsia inteira que lhes abre as portas da grandeza. Em cada casa brilham

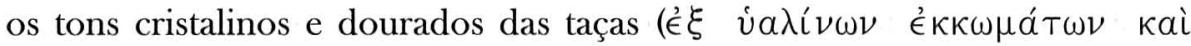
$\chi \rho v \sigma i \delta \omega \nu$, v. 74), transbordantes de um vinho doce e puro ${ }^{(10)}$. O auditório pasma, não só da riqueza que a imaginação engrandece, mas desse mundo de hábitos diferentes, onde os vinhos capitosos se consomem puros, conservada toda a sua força, ao contrário do hábito grego de os diluir com água. Por isso, o espanto dos ouvintes estrondeia na interjeição de Diceópolis, que agora nos traz, num mergulho abrupto, de volta ao mundo grego:? $\Omega$ Kpavvà Tó $\lambda$ เs (v. 75); aí tais notícias soam a gozo e ironia, nos tempos duros que se vão vivendo. É altura de marcar bem a diferença que separa os dois universos, no que agora especificamente respeita aos prazeres da mesa e do sexo. Emitem-se princípios que opõem de base Bárbaros e Gregos; mas a comédia não se conforma, naturalmente, com uma avaliação convencional, favorável a Atenas, antes aproveita para um dos seus habituais remoques (vv. 77-79): 'Embaixador - É que os Bárbaros, os únicos homens por quem

${ }^{(9)}$ Também Ésquilo, nos Persas, insiste na referência aos carros de Sardes (vv. 45-4.7) e ao carro sírio de Xerxes (v. 84).

(10) Sobre a imagem da riqueza e luxo persas que se disseminou entre os Gregos e o testemunho que dela representam também os Persas de Ésquilo, vide E. Hall, Inventing the barbarian, 80-81. 
têm consideração, são os bons garfos e os bons copos. - Diceópolis - É como nós pelos devassos e pelos invertidos'. A própria esquematização da

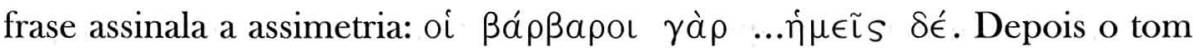

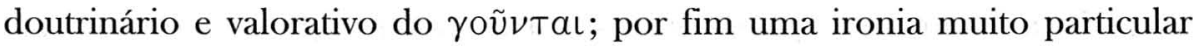

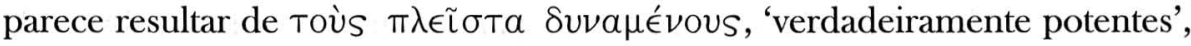
ou seja, 'homens com letra grande', que se é ridículo em relação aos abusos da comida e da bebida, o é mais ainda no que toca à impotência sexual que grassa em Atenas. Logo o lema cómico do Bárbaro é a animalidade, o do Grego a perversão e o vício.

Faltava atingir o clímax da aventura e esse chegou quatro anos após uma longa peregrinação ${ }^{(11)}$. Eis-nos na corte do Grande Rei (vv. 80-82). Apenas o monarca partira, com todo o aparato de uma enorme comitiva, 'levando o exército' como se de uma verdadeira expedição militar se

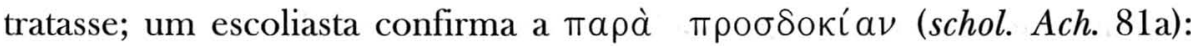

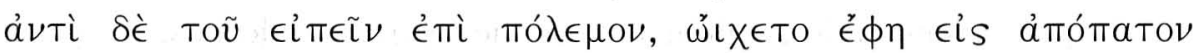

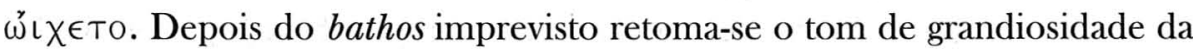
empresa, desempenhada durante oito meses, 'no alto de uns peni...nhascos de ouro' (v. 82). Uma referência final ao ouro traz-nos de volta a magia da riqueza persa, que brota até do solo $^{(12)}$ e está presente nas experiências mais comezinhas do quotidiano. Cassio ${ }^{(13)}$ sintetiza muito a propósito: 'O rei da Pérsia é normalmente transformado num ser fabuloso, com características sobre-humanas até no plano das necessidades fisiológicas, que se move com todo o aparato de homens armados para expedições deste tipo - ou, como aqui, apenas para satisfazer as necessidades'.

Repetiu-se, agora com foros de majestade real, o acolhimento aos viajantes (v. 85). Requintou-se na opulência dos manjares, procurando o monarca fazer jus ao princípio sagrado do seu povo: 'Mais comes, mais

(11) Os emissários que Atenas enviava a um estado estrangeiro para conduzirem uma negociação tinham um tempo de ausência variável, de acordo com a importância da missão, mas que era geralmente de duração limitada, até a uns poucos de dias. Quatro anos é um exagero 'à persa', segundo o qual tudo é multiplicado sobre a prática comum, mas também um excesso 'à grega', onde o sistema democrático permitia a exploração dos cargos políticos, pagos, alguns deles, a peso de ouro pelo erário público.

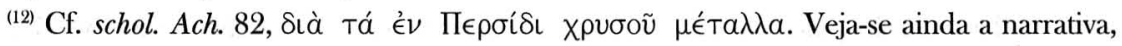
comum entre os relatos de viagem e a historiografia de Heródoto, de campanhas com o objectivo da exploração de riquezas, analisada por Cassio ('Un re di Persia sui monti dell' oro', Eikasmos 2 (1991), 137-141) em relação com este passo de Acarnenses.

(13) Op. cit., 140. 
homem és'. Serviram-se bois inteiros assados no forno (vv. 85 sq.), aves gigantescas. E mais uma vez o confronto com os hábitos gregos é inevitável. Bois inteiros, nunca tal se viu! ... (vv. 86 sq.) na Grécia, onde desde sempre o animal era esquartejado antes de grelhar ${ }^{(14)}$. Aves gigantescas, aí com três vezes o tamanho de Cleónimo ${ }^{(15)}$, da espécie do aldrabão ?!... como imaginar tal petisco! Tem esta história o vago sabor da aventura, que se pode narrar com todos os exageros que a imaginação aconselhar, pela simples incapacidade do ouvinte de confirmar os limites da verdade. Mas toda ela assenta no pressuposto, generalizado entre os Gregos, de um oriente de tesouros incalculáveis e de realidades fantásticas, onde mesmo os seres mais vulgares têm pelo menos três vezes a dimensão das criaturas comuns.

Curiosamente, em data próxima de Acarnenses, talvez até no mesmo ano, Ferécrates apresentava os seus Persas e também ele insistia em tópicos comuns com os de Aristófanes. A coexistência de interesses nas duas peças sugere o impacto das negociações que então Atenas desenvolvia com a Pérsia, no sentido de obter dos cofres orientais apoio financeiro para os seus projectos de soberania da Hélade. A referência a taças de ouro e prata, nos frs. 134-135 K.-A., repõe o tema do banquete sumptuoso; por sua vez o fr. 137 K.-A. parece enumerar um caudal de maravilhas que talvez reproduzissem a Pérsia como um paraíso de abundância e riqueza.

Por outro lado, merece menção a insistência no tema das relações políticas entre Atenas e a Pérsia nos Embaixadores de Platão Cómico ${ }^{(16)}$. É sabido que se tratava aí de uma missão diplomática chefiada por Epícrates, acusado de se ter deixado subornar pelas ofertas magníficas dos Persas ${ }^{(17)}$. Mais uma vez o ouro e a prata resplandecem entre o tesouro arrecadado pelos visitantes (fr. 127 K.-A.).

(14) Também Antífanes (fr. 170 K.-A.) salienta o contraste entre os hábitos alimentares de Gregos e Bárbaros. Os primeiros ou são vegetarianos ou se satisfazem com modestas rações de carne. Os estrangeiros, e devem ser os Persas os visados, têm por norma assar, inteiros, bois, veados ou carneiros.

${ }^{(15)}$ Cleónimo é uma das vítimas predilectas de Aristófanes. O poeta acusa-o de demagogia (cf.Eq. 956-958), de gulodice (Eq. 1290-1299), de perjúrio ( $N u .400$ ), de feminilidade (Nu. 672 sqq.) e sobretudo de cobardia. Em vários passos, Aristófanes refere um momento em que Cleónimo abandonou o escudo no campo de batalha, para mais facilmente salvar a pele (e.g., Eq. 1369-1372, Nu. 353, Pax 444-446, 670-678, 1295-1304), o que, à luz da época, era mais do que vergonhoso, era considerado como crime sujeito a penalidade legal.

(16) Também o poeta cómico Lêucon foi autor de uma peça com este título.

(17) Os frs. 128-129 K.-A. insistem na acusação de gatunos dirigida contra os embaixadores. 
Depois do relato das suas peripécias no país das maravilhas, os emissários de Acarnenses oferecem aos cidadãos de Atenas um exemplar vivo que trouxeram consigo: Pseudartabas, o Olho do Rei. Como um eco, que introduz mais uma vez a suspensão solene antes da aparição espectacular, a voz do arauto anuncia: 'o Olho do Rei' (vv. 92, 94). E, conformando-se também ao esquema regular, Diceópolis atira a sua exclamação, desta vez $\omega \hat{v} \sim \xi^{\prime} H \rho a ́ k \lambda \epsilon \iota s$, o herói da casa, detentor da força, vencedor de tantos inimigos assustadores, capaz de valer às palpitações do seu coração. Porque agora, à surpresa que se traduz em sucessivas interrogações, sobrepõe-se o susto perante tão estranha visão. Mas também, no seu laconismo, as palavras de apresentação delineiam a figura que entra: primeiro o nome, Pseudartabas, depois o título, o Olho do Rei.

De acordo com uma prática generalizada na comédia e muito do gosto de Aristófanes, o poeta cria para a personagem um nome falante, que se ajuste ao perfil da figura que encarna. Claro que a primeira componente, $\psi \in v \delta$-, não deixa dúvidas, é um aldrabão que avança. Mas que tipo de aldrabão? A resposta terá de inferir-se de - $\alpha \rho$ Táßas, que Bailly ${ }^{(18)}$ relaciona com $\alpha \rho \tau \alpha \dot{\beta} \eta$, o nome de uma medida de capacidade persa, citada por Heródoto (1. 192. 2). Logo, no seu conjunto, o nome denuncia 'o que aldraba nas medidas', e talvez o texto venha a defender esta leitura, porque mais adiante, quando se fala das remessas de ouro que a Pérsia mandará 'às rasas' (vv. 107 sq.), a ideia reaparece. Por outro lado, é flagrante a sugestão de nomes persas conhecidos entre os Gregos, como 'A $\rho т \alpha \beta a$ 'tas ov 'A Pers. 980; Hdt. 1. 114. 2), de Olho do Rei confere à personagem um estatuto de nobreza e convívio com a corte. Mas, na versão cómica, esta sugestão implícita é arredada pela exploração concreta do sentido de 'olho': primeiro literal, alusiva ao olho polifémico que a personagem exibe na testa; da mesma forma que os verbos correspondentes, $\beta \lambda \epsilon ́ \pi \epsilon \iota \mathrm{S}$ e $\sigma \kappa o \pi \epsilon \hat{\varsigma}$, valorizados pela posição estratégica em fim de frase, se adequam à função do espia régio; sob o olho, um leque de couro sugere o aparato de uma barba oriental. Por um efeito de sinédoque, o olho é tomado então pelo indivíduo na sua totalidade. Mas logo 'olho' sugere também a Diceópolis portinholas para os remos no casco de um navio de guerra, e é a metáfora náutica que se instala.

(18) Dictionnaire Grec-Français, s. $v$.

${ }^{(19)}$ E. Hall, Inventing the barbarian, 77, a respeito dos nomes irânicos citados por Ésquilo nos Persas, fala da raiz Art- ('O Bem') como comum na antroponímia dessa proveniência. 
Como bem nota Edmunds ${ }^{(20)}$, desmonta-se uma metáfora pela redução ao literal, para se montar, a partir daí, uma segunda (vv. 95-97). Pseudartabas

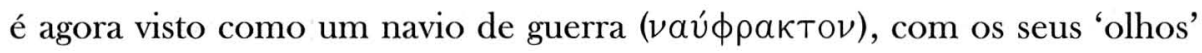
abertos no casco, protegidos, por um painel de couro $(a ̉ \sigma \kappa \omega \mu \alpha)$, da fúria do mar, que procura um local de desembarque ( $\nu \in$ ó $\sigma \circ \kappa_{\kappa} \nu$ ) em terreno inimigo $^{(21)}$. Como espia do rei ou como barco de guerra, Diceópolis prevê em Pseudartabas a ameaça de uma cilada. Acompanham o Olho do Rei, como símbolo da feminilidade inerente ao luxo exótico e excessivo, dois eunucos para o servirem, que, pelos abanos de cabeça que fazem afirmativos e negativos à maneira grega, se denunciam como prata da casa. São Clístenes e Estratão, dois conhecidos exemplares da homossexualidade ateniense, na pele de eunucos persas ${ }^{(22)}$. Com esta surpresa final, num contexto todo ele $\psi \in \cup \delta \eta ́ s$, Aristófanes fecha com um toque de harmonia cómica entre a tradicional feminilidade bárbara e a impotência sexual agora de regra em Atenas (v. 79), de que Clístenes e Estratão são paradigma ${ }^{(23)}$.

Explorada, com abundância de recursos dramáticos e poéticos, a aparência do estrangeiro, passa-se então à linguagem. Também a tragédia fora sensível à necessidade de estabelecer, neste aspecto, diferenças entre o Bárbaro e o Grego. Accionaram-se técnicas variadas para as sugerir, como sejam efeitos acústicos - cacofonias, gritos inarticulados - e a insistência em vocábulos estrangeiros de forma a produzir uma cadência exótica. Nunca, porém, a inteligibilidade foi posta em causa. A comédia, bem pelo contrário, viu na incompreensão ou dificuldade de comunicação uma eterna fonte de cómico. Os diversos modelos que nos restam têm em geral intervenções breves, que partem do totalmente incompreensível para um código mais próximo de um grego estropiado. Assim, depois de um momento inicial perfeitamente enigmático, e perante recomendações repetidas de clareza, as palavras obscuras do estrangeiro ficam ao sabor da interpretação interesseira de cada um.

(20) 'Aristophanes' Acharnians', 4.

(21) Sobre a interpretação desta metáfora, vide Sommerstein, Acharnians, 162; Taillardat, Les images d'Aristophane, 65-67.

(22) Sobre a ideia que os Gregos faziam do eunuco oriental, cf. E. Hall, Inventing the barbarian, 157.

${ }^{(23)}$ Clístenes é vítima, na comédia de Aristófanes, de constantes ataques pessoais. Globalmente a sua imagem é a de uma espécie de símbolo dos efeminados; cf., e. g., Av. 831, Th. 235, 574 sqq. O nome de Estratão aparece-lhe também associado em Eq. 1374. 
É este um esquema já aplicado na cena de Pseudartabas. Uma palavra de incentivo do embaixador - 'vamos, diz lá aquilo que o Grande Rei te mandou comunicar aos Atenienses' (vv. 98 sq.) - e eis que se solta a língua do persa. Como é natural, a obscuridade voluntária deste verso único que pronuncia deu origem a numerosas leituras e a um sentimento mais ou menos generalizado de que Aristófanes quereria sobretudo produzir uma melopeia que soasse a persa, mais do que exprimir qualquer ideia concreta. Note-se, no entanto, que Dover ${ }^{(24)}$, para além de confirmar a simulação de uma cadeia fónica de tonalidade persa, encontra para a frase um sentido:

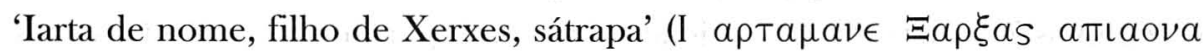
$\sigma \alpha \tau \rho \alpha$, v. 100). Não parece, de facto, difícil de reconhecer uma referência ao nome de Xerxes, o grande rei, e a sátrapa, um título honorífico entre os Persas. Por outro lado, em amıaova julgo entrever uma alusão a Iónios, com a pronúncia que tornava caracteristicamente oriental esta maneira de

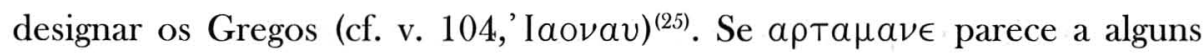
incompreensível, é evidente a semelhança que apresenta com vocabulário variado de origem persa: e. g.,' A $\rho$ та̃ ol, o nome por que se designavam a si

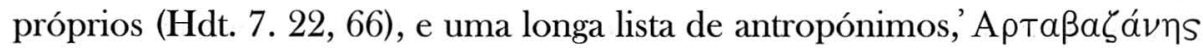
(Hdt. 7. 2, 3),' Арта́ßaらos (Hdt. 7. 66),' Арта́ßavos (Hdt. 4. 83, 7. 10. 1),

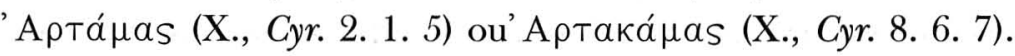

Logo o auditório se concentra em volta da charada que são estas palavras. $\Lambda \epsilon ́ \gamma \in \mathrm{l}$ e $\phi \eta \sigma i ́$ canalizam essa atenção curiosa. A um Diceópolis que se declara incapaz, em absoluto (note-se a forma expressiva da sua negativa, $\mu \grave{\alpha}$ Tòv 'A embaixador dá a tradução que mais lhe convém: que o rei, diz ele, nos vai mandar ... ouro (v. 102). E logo, num esforço para obter a confirmação desta interessante palavra ... ouro (v. 103): 'Diz lá, tu, vamos, alto e bom som, 'ouro'’ De facto, Pseudartabas é agora bem mais explícito (v. 104). Passamos do som persa para o grego estropiado; e desde já Aristófanes

(24) 'Notes on Aristophanes' Achamians', Maia 15 (1963), 8.

(25) Quanto à terminação - $a u$ desta palavra, cf. idêntica pronúncia do deus Tribalo com os

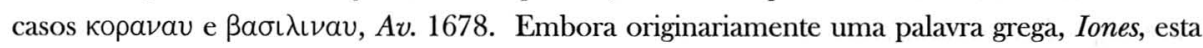
tornou-se a designação geral pela qual os Bárbaros se referiam aos Gregos. Documentos hebreus, assírios e persas têm abonado diversas pronúncias desta palavra, respectivamente jawan, jawnai, yauna, e as várias tonalidades reflectem-se nas versões registadas pelos textos gregos quando atribuídas a estrangeiros; cf. o exemplo das Danaides e dos Persas de Ésquilo (e. g., Supp. 69, Pers. 178, 563, 899, 950, 951, 1011, 1025). 
valoriza certas anomalias que se tornam os erros mais comuns na tentativa de um estrangeiro falar grego: o ditongo da desinência verbal fechado em - ${ }^{(26)} \mathrm{e}$

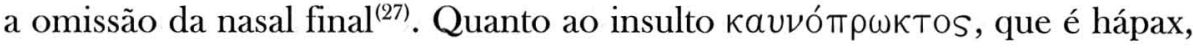
constitui-se de legítimas palavras gregas; talvez, neste caso, Pseudartabas tenda a mostrar-se mais hábil no calão e no insulto, como muitas vezes acontece com o falante de conhecimentos limitados numa outra língua. Agora, perante a evidência das palavras, os ouvintes mudam de campo: Diceópolis entendeu claramente e é o emissário de Atenas que finge não ter percebido. A tentar até compor a situação, procura para kavvo- uma substituição homófona, e fala de 'rasas', de ouro às rasas, ảkávas. O teste final far-se-á pelo argumento convincente da bengalada: ao bárbaro promete-se, de forma que lhe não deixe dúvidas, um banho de Sardes ${ }^{(28)}$, que tem o condão de lhe fechar a boca e de o reduzir a um tímido aceno de cabeça. Explora-se assim a cobardia que os Gregos consideravam característica de Bárbaros, ao lado do seu inverso, a brutalidade, de que os Odomantos de Acarnenses e o guarda cita de Tesmofórias são exemplos. Muito breve, este diálogo em que participa Pseudartabas soma toda uma gama de efeitos: psicológicos, nas reaç̧ões que provoca nos vários intervenientes; linguísticos, como fonte de constantes qui pro quo cómicos, com uma exuberância capaz de satisfazer todos os gostos.

A assembleia prossegue com uma cena paralela, através da presença de um novo emissário de Atenas, desta vez à corte trácia de Sitalques. Vários argumentos poderiam justificar esta insistência: decerto, antes de mais, o próprio envolvimento da Atenas real numa rede intrincada de relações exteriores, que a comédia caricatura; ou mesmo, na opinião de Long ${ }^{(29)}$, a articulação coerente de dois projectos atenienses: conseguir ouro persa para contratar mercenários belicosos do norte; em consequência, a confirmação das apreensões 'dramáticas' que afligem Diceópolis; por fim, o ensejo para aproveitar ainda um motivo cómico, por efeito de contraste com a cena precedente.

(26) Cf. o mesmo erro repetido com frequência na fala do Cita, infra.

(27) Da mesma forma cf. a fala do Cita, infra.

${ }^{(28)}$ Outros passos de Aristófanes documentam também a tradição de Sardes como produtora de tecidos e roupas majestosas ( $V$. 1136-1149), particularmente tingidos de púrpura (Pax 11731174); cf. ainda A., Pers. 317.

(29) Barbarians in Greek comedy, 94. 


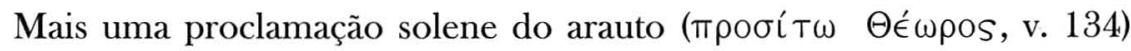
e eis-nos diante de Teoro, recém-chegado da Trácia. Desta vez, à rubrica genérica $\pi \rho \in ́ \sigma \beta \in L S$ 'os embaixadores', substitui-se um nome e uma figura autêntica da Atenas de então(30). De comum com os seus colegas Teoro evidencia um padrão que Diceópolis uniformiza com o epíteto $a \lambda a \zeta \omega ́ v$ 'parlapatão' (cf. vv. 63, 87, 135). Também o desenvolvimento da cena prossegue dentro do plano anterior. Primeiro a descrição da viagem define o ambiente geográfico e social da comunidade trácia: o percurso foi imenso, através de planícies extensas e geladas, cruzadas de rios intransitáveis (vv. 136-139). Se confrontados com a descrição da viagem pela Pérsia (vv. 68-71), estes versos mostram como, em palavras sumárias, se pretende determinar diferenças fundamentais. Não se trata, portanto, de estabelecer um retrato mais ou menos convencional para o universo não grego, mas de empolar traços nítidos que definam a identidade de cada espaço. Da Trácia é característico o clima agreste, que cobre de uma neve uniforme uma paisagem vasta de planícies cortadas por rios. A ausência de referências a ostentação e luxo faz da Trácia um reino mais sóbrio, de que não se espera ouro ou prata, mas antes a força, temperada pelos rigores do clima, do seu exército ${ }^{(31)}$. A recepção na corte saldou-se pelos brindes oferecidos pelo rei aos hóspedes gregos, sem mais requintes de serviço; no entanto, se a predilecção pelo álcool aparece como um traço comum no desenho do bárbaro em geral ${ }^{(32)}$, ela é em particular relacionada com os Trácios ${ }^{(33)}$. Do calor do seu acolhimento acentua-se sobretudo a simpatia humana;

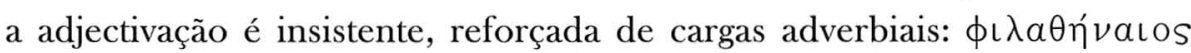

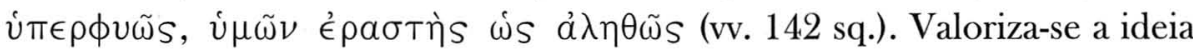
de um convívio e de uma permuta cultural intensa. O rei projectava, com legendas políticas nas paredes, uma campanha de entusiasmo pelos interesses gregos; o filho, que fora distinguido com a cidadania ateniense (cf. Thuc. 2. 29. 6-7), ansiava por tornar concreta e participada essa relação. Tudo cheira,

${ }^{(30)}$ Esta mesma personagem é referida em V. 599, 1220, 1236-1237, como companheiro de

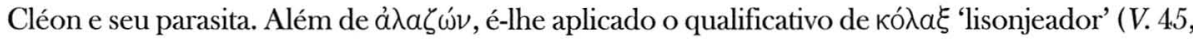
418). Como também é histórica uma aliança que Sitalques fez com Atenas em 432 a. C.

(31) Também na tragédia se fixa para os Trácios o perfil da agressividade e violência. E. Hall, Inventing the barbarian, 104-110, selecciona exemplos diversos e expressivos.

${ }^{(32)}$ Cf. supra p. 243 sobre a recepção persa aos enviados atenienses.

${ }^{(33)}$ Cf. Pl., Lg. 637e; Eur., Rhesus 418-419. 
neste quadro optimista e amigável, a uma profunda ironia, já que sempre houve entre os Gregos o sentimento de uma inveja ou rivalidade por parte dos Bárbaros contra a Grécia, o iminente e sempre ameaçador 'perigo bárbaro' $^{(34)}$. Por trás do exagero cómico, adivinha-se, com a Pérsia e a Trácia, políticas de pressupostos diversos: a caça ao dinheiro persa e a consolidação de apoio militar com os povos do norte. Logo de Sitalques se colheu uma promessa de auxílio e cooperação (vv. 147-148) através do envio de tropas bem treinadas, as mais aguerridas dessas paragens, os Odomantos ${ }^{(35)}$.

Mais uma vez, da descrição se passa ao espectáculo: um anúncio solene do arauto, 'o exército dos Odomantos!' (v. 156) e vemo-nos colocados diante de um exemplar ao vivo, agora um colectivo armado. É altura para as interrogações surpreendidas de Diceópolis, com a função dramática de acentuarem os aspectos essenciais do quadro. Um lançar de olhos geral e de imediato toda a atenção do nosso herói se concentra num ponto menor, Toutí (v. 157), тò té́os descascado dos Odomantos. Sem que haja no texto qualquer referência explícita ao trajo dos Trácios, não será difícil de os imaginar sob os adereços convencionais para a sua caracterização: a túnica curta, que exibe sem dificuldade o sexo, a espada e o escudo típico deste exército (cf. Hdt. 7. 75; Eur., Alc. 498; Ar., Lys. 563). O requebro efeminado dos eunucos persas dá lugar à macheza agressiva dos Trácios, capazes de arrasarem, pela força, a Beócia inteira - desde que se lhes pague um bom salário, claro está! Este roubo previsível é antecedido de uma actuação imediata, que antecipa a 'colaboração' futura. Mal chegados, já os Odomantos se lançam sobre Diceópolis, para lhe saquearem do alforge uns tristes dentes de alho. Para os Trácios, o tesouro é a Grécia, 'os montes dourados' a Pnix de Atenas.

A cena do estrangeiro é aqui aligeirada pela omissão do cómico de linguagem, mas no que respeita ao esquema em geral - espalhafato da apresentação que suscita surpresas e comentários, caracterização de costumes e atitudes de uma comunidade estranha - inteiramente circunscrita a um padrão convencional.

(34) Esta ideia, expandida no teatro cómico e trágico, tem uma expressão nítida em Pl., $R$. $470 \mathrm{a}-471 \mathrm{~b}$.

(35) Localizados entre os rios Estrímon e Nestos, os Odomantos eram considerados os povos mais belicosos da Trácia. Cf. a referência que lhes é feita por Th. 2. 101. 3. 
Mais tarde, em Aves, Aristófanes volta à sátira das negociações internacionais, mas desta vez dilatadas ao universo da pura fantasia. É Nefelocucolândia, na pessoa do seu chefe Pisetero, quem acolhe e negoceia com uma missão enviada do Olimpo. Nela se integram Posídon, como responsável pela embaixada e procurador dos interesses de Zeus, Hércules, o herói brutamontes e esfomeado, e Tribalo, em representação dos deuses bárbaros. As fronteiras separam, neste caso, a cidade das nuvens e dos cucos do Olimpo; mas, mesmo na morada das divindades, há barreiras, que distinguem os deuses civilizados dos bárbaros. E para caracterizar essa original espécie divina, Aristófanes inspira-se mais uma vez na Trácia, onde habitam os Tribalos humanos, conhecidos, pelos seus vizinhos gregos, como um primor de selvajaria ${ }^{(36)}$. E a cena não se limita a uma paródia etnográfica; embora tudo se passe no reino do absurdo, o poeta repete o esquema já usado nas embaixadas terreais, movimentando temas de sátira política, mitológica e popular num momento de grande aparato.

Também em Aves a entrada do estrangeiro divino é precedida de uma apresentação, feita em visita antecipada por Prometeu, que denuncia os bastidores da missão. É-nos então referenciado o reino dos deuses

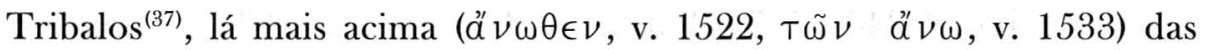
paragens governadas por Zeus. Esse 'mais acima' representa, nas alturas do Olimpo, os confins. Assim se encontram afastados dos acessos e do circuito dos abastecimentos, barrados por uma margem litoral de deuses civilizados, pelo que exigem a Zeus a abertura imediata dos mercados à importação dos fumos dos sacrifícios. Este é o modelo do Bárbaro remoto, sem meios próprios de subsistência, a cuja porta a fome bate se os vizinhos, mais fortes, lhe boicotarem o abastecimento. Apesar de a crise ser geral no Olimpo, são os Tribalos quem mais depressa reage à fome e se manifesta com exuberância (vv. 1520-1522). A sua reacção é a do instinto primário, estimulado por carências elementares ( $\pi \in\llcorner\nu \tilde{\omega} \nu \tau \epsilon S)$. À fome respondem em

(36) Sobre a relação dos Tribalos com a Trácia, vide Th. 2. 96. 4; Str. 7. 3. 8. Sobre a ideia que os Gregos faziam dos Tribalos, cf. infra n. 37.

(37) Para estes deuses bárbaros Aristófanes vai buscar inspiração às montanhas da Trácia, onde uma tribo com este nome ocupava um território que hoje corresponde ao ocidente da Bulgária (Hdt. 4. 49. 2; Th. 2. 96. 4). Também na geografia real, esses territórios recuados estavam separados do mar por uma faixa litoral ocupada por Gregos. A imagem que os Helenos tinham deste povo atribuía-lhes um comportamento selvático e violento (cf. Arist., Top. 115b 22-26; Alexis fr. 243 K.-A.; Isoc. 12. 227). 


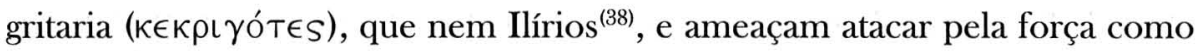
uma autêntica horda bárbara. Predomina no quadro a irracionalidade e o instinto. Descrito o comportamento e feita uma alusão vaga à linguagem, retoma-se o cómico obtido do nome. Nome que não resulta neste caso da criação do poeta, mas que se presta a uma original e imaginativa interpretação semântica: 'Tribalo ...', depreende Pisetero, 'é então daí que vem “não se me dava estripá-lo”' (v. 1530). É patente, para o senhor de Nefelocucolândia, a

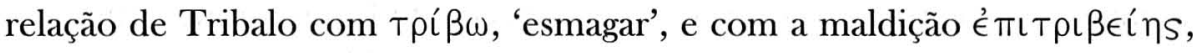
‘que fiques esmagado, estripado' (cf. Ach. 557).

Feitas as apresentações prévias, chega a anunciada comitiva, o mesmo é dizer o sempre aguardado momento da aparição do bárbaro. Cabe agora a Posídon assinalar, com as infalíveis interrogativas de espanto, o comportamento ou o aspecto inusitado da figura. Desta vez as atenções vão para o trajo (vv. 1567-1573). Um trajo que é, afinal, o vulgaríssimo i $\mu \alpha ́$ Tıov, o manto grego, apenas preso ao contrário, sobre o ombro direito, a envolver o corpo da direita para a esquerda, e a descair para as pernas, como se quisesse esconder qualquer mazela, que nem o coxo do Lespódias ${ }^{(39)}$. A interjeição permanente neste contexto apela agora à democracia, ou seja, a Atenas, segundo cujos padrões se julga aquela actuação desastrada; mas também a uma Atenas que, apesar de tudo, se não poupa a erros semelhantes de responsabilizar parolos por missões de importância. Um simples é $\chi \in \in S$ ả $\tau \rho \epsilon ́ \mu \alpha S$, 'ora fazes favor de ficar quieto!', permite à nossa imaginação recriar os gestos atrapalhados com que o bárbaro procura solucionar a dificuldade. É esta uma sequência em que o gesto e o movimento vão além do efeito das palavras.

Com o decurso das negociações, chega o momento em que cada um dos participantes será chamado a pronunciar-se em assuntos gradualmente mais espinhosos, ou, no que respeita ao bárbaro, da costumeira paródia da linguagem. A primeira proposta, adiantada por Pisetero, está na mesa:

${ }^{(38)}$ Sobre os Ilírios, vide Strab. 7. 5. 10. Do seu contacto histórico com os Ilírios guardavam os Gregos memória de um ataque daquele povo, instalado num território coincidente com as modernas Albânia e Macedónia, contra a Grécia e, em particular, contra Delfos (cf. Hdt. 9. 4243; Eur., Ba. 1333-1338).

(39) Lespódias foi um político ateniense em evidência em vários momentos da história de Atenas, recente em relação à data de Aves; assim, no próprio ano de 414, recebia uma chefia militar que o levou a actuar num ataque contra a Lacónia (Th. 6. 105. 2). A sua imagem cómica acentua-lhe a personalidade belicosa (cf. Phryn. Com.fr. 17 K.-A.) e refere-lhe sobretudo as pernas tortas, que pretendia disfarçar deixando descair a túnica (Theopomp. Com. fr. 39 K; Eup. fr. 107 K.-A.). 
uma aliança entre deuses e aves que resultaria no reforço do poder dos Olímpicos. Conseguido, sem dificuldade, o voto de Posídon e Hércules,

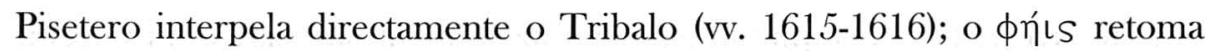
o tópico: 'e tu, que dizes?' Em resposta, o Tribalo avança com um $v a$

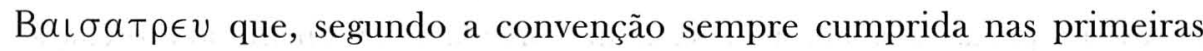
palavras de um estrangeiro, é totalmente incompreensível ${ }^{(40)}$. É claro que também nem Posídon nem Hércules o entendem. Simplesmente Hércules, já impaciente pelo almoço e, por isso, disposto a todos os assentimentos, se apressa a ler uma pacífica anuência nas palavras do Tribalo. De onde resulta não só um efeito de comicidade para a figura do bárbaro, como também para a do tradicional Hércules comilão. É o interesse pessoal que move o herói da força, como antes o embaixador em Acarnenses ${ }^{(41)}$, apenas agora o seu alcance não ultrapassa a urgência do apetite.

Passa-se à discussão mais delicada da entrega ao senhor das aves do ceptro de Zeus, símbolo da soberania olímpica sobre o universo (vv. 1626 sqq.); cabe a Hércules encarregar-se de interrogar o bárbaro, o que lhe dá a ocasião para apelar ao seu segundo atributo cómico, a força bruta (vv. 1628-1629). Com este novo interlocutor, armado de varapau, a pergunta sacramental - 'o que tens tu a dizer?' - ganha variedade: 'E que te parece de uma boa carga de pau?’ A pressão da ameaça torna mais ágil a língua do Tribalo, cujas palavras resultam, por isso, mais inteligíveis; na sua

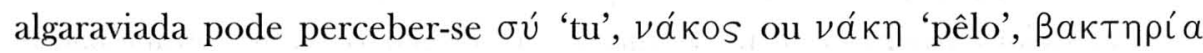

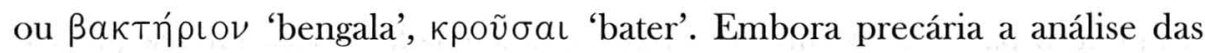
palavras do bárbaro, parece que, em termos fonéticos, os desvios assentam em princípios distintos dos que se aplicou a Pseudartabas. O $\eta$, que o persa conhecia $(\lambda \eta \psi$ L, v. 104), aparece na fala do Tribalo com a tendência dórica para ser substituído por $\alpha, v a ́ \kappa \alpha, \beta a ́ \kappa \tau a \rho ı$; por outro lado, a mutilação das finais de palavra, afectadas nos dois casos, são-no de forma diversa (veja-se,

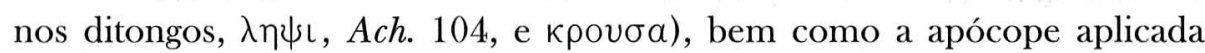

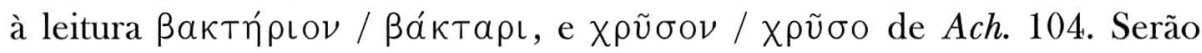
estas diferenças de pormenor entre a fala dos dois bárbaros voluntárias, tal como hoje um português caricaturaria de forma diferente um inglês ou um alemão que pretendesse falar a sua língua? Do susto do bárbaro, Hércules

\footnotetext{
${ }^{(40)}$ É opinião generalizada entre os editores da peça a inutilidade de tentar encontrar para esta palavra um sentido; cf., e. g., Coulon, 102; Sommerstein, 304.

(41) Vide supra, 248-249.
} 
infere mais uma vez a concordância: 'Diz ele que as minhas palavras são justíssimas'. Ouvidas as duas 'opiniões', Posídon adere em último lugar à entrega a Pisetero do ceptro de Zeus, na posição daquele cujo voto não é decisivo perante a opção já expressa da maioria, agora que a questão representa uma primeira cedência das divindades.

A revolta de Posídon estala perante a última exigência de Pisetero. Darlhe em casamento a bela e jovem Basíleia e deixar a Zeus apenas Hera?!!! Como despojar o deus supremo, desta forma, da vitalidade do seu poder soberano? O chefe da embaixada está disposto a abandonar sem mais a mesa das negociações; mas Hércules, estimulado pelos argumentos, jurídicos neste caso, de Pisetero, cede. Fica-se num impasse, que Tribalo terá de resolver. Tudo depende, portanto - ironia das ironias! -, das palavras do bárbaro (vv. 1677-1682)(42). $\Lambda \epsilon ́ \gamma \in \mathrm{t} \nu$ repetido em fim de versos sucessivos dá a tónica da questão. Depois de pedida a opinião do bárbaro, seguese a controversa interpretação das suas afirmações. Dunbar ${ }^{(43)}$ acentua a

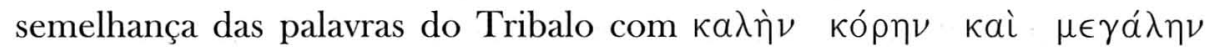

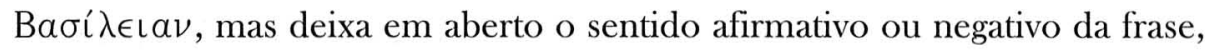
dependente da hipótese de ler $a \hat{v}$ ( $\beta \alpha \sigma \iota \lambda \iota \nu$ - $\alpha \hat{\text { ) }}$ como equivalente a oủ. $\mathrm{Na}$ cadeia fonética que o bárbaro articula repetem-se tendências já antes

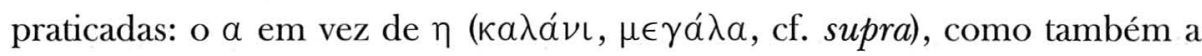
mutilação das finais de palavra (ỏ $\rho \nu\llcorner T$ ); é ainda visível o estranho som - $\alpha v$ em termo de vocábulo ( $\beta a \sigma \iota \lambda \iota v a \tilde{v}$, como antes $\sigma a v)$, para além da ausência

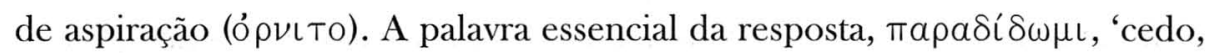
entrego', é, porém, inconfundível e, por isso, todos se lhe rendem, Hércules com agrado, Posídon com relutância. E numa tentativa de condicionar a cedência, o chefe da embaixada dá a sua leitura, ambígua, do contexto. Àquilo que parece relativamente claro, 'essa bela e esbelta Basíleia entregoa às andorinhas', apõe o deus uma condição, 'a não ser que ela caminhe como as andorinhas', o que é uma leitura particularmente duvidosa do texto. As dificuldades de compreensão são enormes, dado que a ideia de

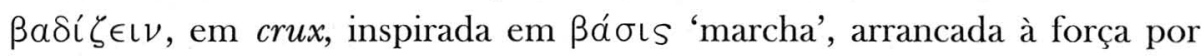
Posídon de $\beta a \sigma \iota \lambda \iota v a v ̃$, levanta grandes problemas. Não deixa de ser curiosa a informação dada por Coulon (105) de que, na concepção dos antigos, uma andorinha voa ou pousa, não anda. A admitirmos esta leitura, 'a não ser

\footnotetext{
${ }^{(42)}$ Prefiro desta vez a leitura de Sommerstein para este passo tão controverso. (43) Aristophanes. Birds, 735.
} 
que ela caminhe como as andorinhas' seria um adynaton, correspondente a 'quando as galinhas tiverem dentes', ou seja, 'nunca'. A esta interpretação forçada de Posídon, logo Pisetero contrapõe outra não menos forçada, 'ou seja, portanto, diz ele que ela seja entregue às andorinhas'.

Em conclusão, uma trama em comum suporta estas diversas cenas, ainda que sobre ela o poeta produza alterações de pormenor e adaptações que lhe introduzem alguma novidade. A transposição essencial da realidade para a fantasia é, no caso de Aves, o toque de uma comicidade inédita sobre padrões vulgares.

A figura do estrangeiro revestiu ainda, sem sair do âmbito da paródia política, outras perspectivas, nomeadamente aquela que respeita à definição de um novo modelo de político, de origem remota e exterior à sociedade ateniense. Este é o caso do Paflagónio / Cléon de Cavaleiros (ou do Máricas / Hipérbolo de Êupolis, que segue de perto a personagem de Aristófanes), embora o poeta não explore a faceta bárbara, para além do nome e origem que atribui ao demagogo. Outros comediógrafos, porém, ao atacarem a nova classe política, conciliaram com essa caricatura traços inseparáveis da identidade cómica do estrangeiro. Assim, a julgar pelos fragmentos conservados, a comédia que Platão Cómico dedicou a Hipérbolo e a que deu o seu nome. O schol. Luc. Tim. 30 p. 114, 28R atesta que Hipérbolo aparecia na peça de Platão como 'um lídio', do sangue de Midas; e o schol. Pax 692 regista que uma outra opinião ateniense o via como um sírio. O fr. 182 K.-A. comprova, ainda que em tom genérico, a mesma opinião,

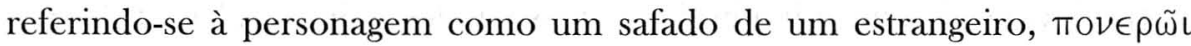

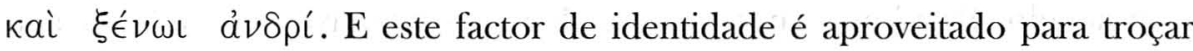
da linguagem bárbara da personagem (fr. 183 K.-A.): 'O grego dele não era como o nosso, benza-nos Deus. Quando queria dizer $\delta\llcorner\eta \iota \uparrow \omega \eta \eta \nu$, articulava

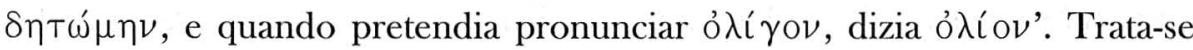
de um meteco, um residente estrangeiro em Atenas, cuja linguagem é já o grego e portanto inteligível; apenas algumas deficiências de pronúncia lhe denunciam a origem bárbara. O mesmo Platão Cómico, na sua peça Cleofonte, repetia o processo, pondo desta vez a mãe do político a dirigir-se-lhe em língua estrangeira, dada a origem trácia que lhe era atribuída (fr. $61 \mathrm{~K}$.-A.). Esta personagem do estrangeiro residente tornou-se relativamente comum na comédia antiga, a julgar por alguns vestígios, como o título Metecos de uma peça também de Platão Cómico, poeta que, pela soma de indicativos aqui aludidos, parece ter recorrido com alguma frequência a este tipo. 
Mas o modelo mais expressivo, porque o único integralmente conservado, da figura do estrangeiro residente, é o polícia cita que Aristófanes inclui em As mulheres que celebram as Tesmofórias. Representa esta personagem o escravo de proveniência não grega, sem dúvida o tipo de estrangeiro que o Ateniense melhor conhecia do seu convívio diário e em boa parte o responsável pelo preconceito de superioridade que sentia perante o bárbaro.

Os archeiros citas, sob a superintendência dos magistrados, desempenhavam em Atenas, entre outras, funções de policiamento. Tinham um estatuto de escravos públicos e aparecem activos nesta função durante o séc. V a. C. O símbolo da sua actuação era o arco e a flecha (Th. 1197), armas tradicionais dos Citas ${ }^{(44)}$; sem dúvida que estas são as insígnias principais da sua caracterização exterior na comédia, para além do chicote (Th. 1125) e do sabre (Th. 1127), insígnias da sua actuação policial. Banais no dia-a-dia da Atenas clássica, vemo-los actuantes em diversos momentos da produção de Aristófanes. Logo em Acarnenses (vv. 54-58), os archeiros citas aparecem encarregados de manter, à ordem do prítane, a normalidade na assembleia do povo; em Lisístrata (vv. 433-462), é com a sua colaboração que o Proboulos se propõe aprisionar as mulheres revoltosas. Mas só em Tesmofórias, onde lhe cabe vigiar o prisioneiro e manter afastadas as visitas suspeitas, o Cita tem um verdadeiro papel dramático, aliás extenso e bem desenvolvido.

Vemo-lo, em primeiro lugar, no exercício rotineiro das suas funções. A actuação que desempenha não é isenta de alguma brutalidade e indiferença pela sorte do prisioneiro, a que se soma uma grande dose de estupidez. Se o pobre lhe pede que abrande um pouco a pressão da canga, ele aperta mais, por impiedade, talvez, ou simplesmente por não saber como apertar ou desapertar a arma do suplício ${ }^{(45)}$. Seja qual for o motivo da sua atitude, o resultado é infalível: divertir o público com os gritos ridículos de Mnesíloco, na pele de uma matrona improvisada. À brutalidade soma-se a negligência, que lhe sugere a ideia de ir buscar uma esteira para ... se deitar de guarda ao prisioneiro (v. 1007).

(44) E. Hall, Inventing the barbarian, 4.2, salienta que o arco, associado pela tradição sobretudo aos Troianos e, na época clássica, aos Cretenses e Citas, era desprezado e considerado sinal de cobardia (embora ligado também a alguns heróis gregos em particular, como Filoctetes e Ulisses).

${ }^{\left({ }^{4}\right)} \mathrm{Na}$ interpretação de Long, Barbarians in Greek Comedy, 106 sq., a personalidade do Cita alia a crueldade à estupidez. 
Mas mais do que o aspecto exterior ou o retrato psicológico, é sem dúvida a linguagem que desde logo se impõe como o traço por excelência do desenho da figura. Naturalmente que o Cita fala um grego estropiado, mas compreensível, e, porque a comunicação está assegurada, o poeta pode alargar a exploração da sua oralidade, e não restringir-se, como para o caso do estrangeiro apenas visitante, a meia dúzia de palavras. O móbil do riso é portanto a paródia de um linguajar que a população de Atenas bem conhecia e identificava com a personalidade popular do archeiro cita. Não satisfaz pensar que o discurso da personagem é um código inteiramente arbitrário, mas antes que reproduzirá, mesmo se de forma não sistemática, características típicas e bem identificadas como deste tipo social. Assim a variedade da desinência verbal tende a limitar-se a um repetitivo -ı final (cf. Ach. 104), sem ter em conta pessoa nem tempo: oi $\mu \tilde{\omega} \xi \iota$ (v. 1001) ou

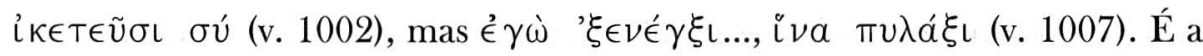
situação paralela à de um estrangeiro dos nossos dias que, colocado perante uma língua com um sistema verbal complexo para os seus hábitos linguísticos, tende a defender-se com um simples infinitivo. Verifica-se também uma tendência para a mutilação da nasal final, perante consoante, dos nomes, adjectivos ou advérbios, como é o caso de $\mu \tilde{a} \lambda \lambda$ o (v. 1005, cf. Ach. 104),

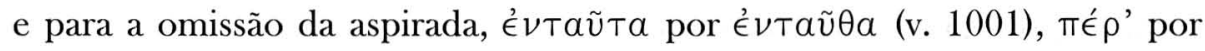

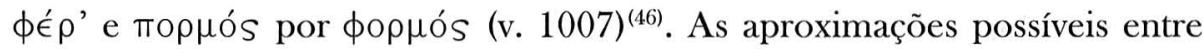
alguns destes pormenores de pronúncia do Cita com situações idênticas na linguagem de Pseudartabas não serão decerto ocasionais. Invoco, sobre esta coincidência, a afirmação de E. Hall ${ }^{(47)}$ que, ao salientar a acuidade auditiva de Aristófanes para as línguas estrangeiras, observa: 'Aristófanes tinha uma ideia clara do tipo de sons que os Persas produzem e, dado que o cita era uma língua do grupo indo-irânico aparentada com o persa, não há razão para pensar que ele não fosse capaz de imitar a pronúncia do cita do dialecto ático’. A esta afirmação eu acrescentaria que não seria surpreendente, em consequência, que Aristófanes se tivesse apercebido das semelhanças entre as duas línguas e as registasse na sua caricatura.

Mas a este polícia, já cómico na sua vulgaridade, Aristófanes reserva uma aventura teatral que contribui para o desnortear por completo. Por

(46) Quanto à omissão de aspiradas, o cita diverge do persa, que as pronuncia sem dificuldade

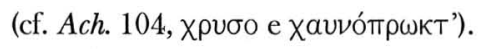

(47) 'The archer scene in Aristophanes' Thesmophoriazusae', 39. 
desgraça sua o prisioneiro é parente de um poeta engenhoso, Eurípides, e tem com ele uma conivência que lança o polícia numa odisseia literária. Aí a incompreensão total do Cita perante a situação determina-lhe novas facetas: antes de tudo, ignorância completa dos sucessos teatrais de Eurípides, ou mesmo da mais rasteira tradição mitológica; o mundo grego continua, portanto, a ser para ele um universo estranho. Soma-se-lhe a estupidez que o inibe de tirar qualquer interpretação lógica dos acontecimentos, e uma certa irritabilidade que daí resulta. Deste conjunto de factores se ressente a língua, progressivamente mais gaguejada nas suas inúmeras e bem marcadas aliterações.

Ei-lo, sem preâmbulo, lançado na reconstituição paródica da Andrómeda; transformado em sofredora donzela, Mnesíloco recebe de Eco, aqui assegurada pelo próprio Eurípides ${ }^{(48)}$, a repetição solidária com os seus lamentos. É portanto o poeta de golpes romanescos que a comédia traz à cena, para lhe ridicularizar as ousadias. Mas aos olhos prosaicos do guarda, a leitura da situação resume-se à presença do prisioneiro, abordado por uma mulher desconhecida, reduzida a misteriosa voz feminina, que se limita a repetir, de forma absurda, tudo o que ouve, até os seus barbarismos. Já cheio de suspeitas, desnorteado por uma correria inútil atrás de uma voz, o Cita ameaça primeiro chamar os prítanes, seus superiores hierárquicos. Mas à

${ }^{(48)}$ Segundo Coulon (62), e ao que julgo com razão, o entendimento dramático desta cena deverá ser o seguinte: a voz de Eco, que na peça de Eurípides se ouvia à distância, produzida fora de cena, será aqui produzida, também fora de cena, pelo próprio Eurípides, o cúmplice de Mnesíloco na trama contra o Cita. Esta voz, que desespera o archeiro, fá-lo correr desnorteado em cena, numa busca inútil. Desta leitura resultam diversas vantagens: é mais divertida, porque transtorna o Cita por completo, mais próxima do original euripidiano, além de deixar livre o Eurípides cómico, para entrar em cena, logo de seguida, como Perseu. Sommerstein (Thesmophoriazusae, 227), no entanto, assinala certos pontos do texto que lhe parecem sugerir, de forma clara, que Eco é trazida à cena: entende este autor que a forma como Mnesíloco se lhe dirige é tão natural como se os dois estivessem em presença, sem que nada nas suas palavras denuncie qualquer estranheza perante uma voz incorpórea. E acrescenta o pormenor de que o Parente trata Eco por 'velha' (v. 1073), o que implicaria que a visse. Não entendo decisivos estes argumentos que esquecem a conivência de Mnesíloco com o Eurípides ausente e as suas produções. Ao colocar-se no papel da Andrómeda do 'ano passado', como iria ele estranhar a voz de Eco ou que hesitação teria em tratá-la por 'velha', quando era para ele evidente que a voz que lhe respondia de longe era o seu cúmplice natural, o 'velho' Eurípides? Este assunto merece uma ampla discussão em H. Hansen, 'Aristophanes' Thesmophoriazusae: theme, structure and production', Philologus 120, 1976, 165 185; vide ainda MacDowell, Aristophanes and Athens, 269, sobre as divergências de interpretação que a execução cénica deste episódio tem suscitado. 
medida que todas as suas palavras só encontram ressonância na repetição de Eco, a paciência abandona-o e as advertências tornam-se mais ridículas pelo tom de animosidade burlesca que ganham. Sobretudo a irritação da autoridade, que se sente troçada, transparece da linguagem. Os traços de linguagem que lhe são próprios regressam: a terminação - - aplicada aos

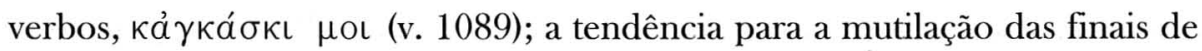

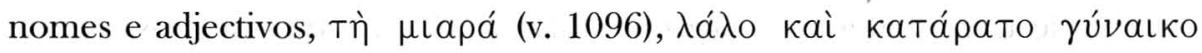
(v. 1097); a omissão das aspiradas, agora mais insistente, $\pi \omega \nu \eta \dot{~ p o r ~} \phi \omega \nu \eta ́$

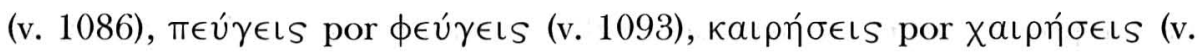
1094); soma-se-lhes a tendência para a confusão do género, sempre vulgar

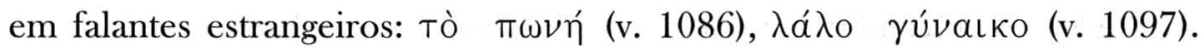
Significativa é, nesta cena, a propensão para o vulgarismo (cf. $\gamma \rho u ́ \zeta \epsilon \mathrm{L}$, v. 1095) e sobretudo as aliterações que traduzem o nervosismo do guarda,

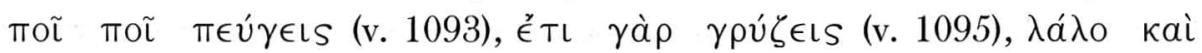
ката́рато үúvalко (v. 1097).

Depois de se voltar contra o Parente / Andrómeda e o Eurípides / Eco, é contra o Eurípides / Perseu que se debate. A presença de Perseu, no papel de um jovem fulminado pelo amor à primeira vista por uma donzela condenada e sofredora, leva a conversa para um novo rumo, o da paixão; e, neste campo, outra faceta do bárbaro se revela. Naturalmente que o contexto trágico continua a escapar-lhe por completo, mas a componente erótica da situação provoca nele comentários obscenos, à medida de uma criatura grotesca e grosseira.

A aventura famosa do Perseu do mito, assassino da Górgona Medusa, é episódio de que o Cita não tem a menor luz. Ao ouvir o nome de Górgona, confunde-o até com o de um escriba da Atenas do momento ${ }^{(49)}$ (vv. 11021103). Os desvios são os de sempre: terminação verbal -l, apócope de finais, ausência de aspiradas. Mas quando o Perseu de ocasião dirige à improvisada 'donzela' prisioneira palavras de piedade e emoção, o Cita esforça-se por desfazer o mal entendido. Explora-se então a vulgaridade da linguagem sexual num tom de crescente ousadia (vv. 1111, 1114, 1119-1120). Mais do que nunca o Cita comete erros constantes de género, que ultrapassam aqui a mera incapacidade linguística, para se tornarem hilariantes na situação;

(49) Equívoco semelhante é feito antes pela mulher de guarda ao prisioneiro, que, nos vv. 874-876, confunde o Proteu da mitologia com um cidadão ateniense com o mesmo nome. Deste Górgon há um registo numa inscrição do séc. V a. C., IG I 433, col. III, 32. 
porque afinal o bárbaro defronta-se com um sujeito que parece incapaz de distrinçar os sexos fisiológicos e que continua a insistir, apesar das evidências, em que o prisioneiro é uma delicada virgem.

Perante o insucesso das suas tramas literárias, Eurípides afasta-se, convicto de ter perdido a batalha, mas não a guerra. Bastará, para vencer a resistência inimiga, adoptar-lhe as armas, ou seja, aproveitar-lhe a estupidez e a sensualidade. Por isso o poeta que regressa, sob o exterior de uma velha alcoviteira, vem acompanhado de uma esbelta bailarina de carne e osso, encarregada de cativar as boas graças do Cita. Desta vez a artimanha resulta em cheio. Agora no seu elemento, o archeiro vibra à aproximação do grupo animado, que lhe lembra um komos festivo (v. 1176). E todo ele se empolga com o rodopio da bailarina que lhe saltita em torno (v. 1180). Tomado pela alegria da festa popular, a sua linguagem deixa o tom meramente declarativo e torna-se emotiva, capaz até de uma imagem coloquial para definir a leveza da dança. Como resistir ao fascínio da dançarina que se lhe senta nos joelhos (vv. 1183-1185)? As palavras saem-lhe exaltadas, fartas de repetições, exclamações, comparações. Ao narrativo sobrepõe-se o emotivo, sem que se perca a marca oral típica do guarda (vv. 1188, 1191-1192). Para além da sonoridade bárbara, a linguagem do estrangeiro funciona neste caso como um factor de caracterização psicológica do próprio Cita, enquanto nos anteriores o efeito se produzia pela forma como os outros interlocutores reagiam ou aproveitavam os barbarismos incompreensíveis.

Difícil não foi a Eurípides afastar a atenção do Cita durante o tempo suficiente para a fuga do prisioneiro. De resto, afogueado pela paixão, o archeiro depõe armas, pela entrega simbólica do arco como caução do amor. Um toque de ironia final legenda a situação. À pergunta do Cita 'como te chamas?', Eurípides responde com um 'Artemísia' (v. 1200), o nome da famosa rainha da Cária ${ }^{(50)}$, célebre pela inteligência, que o Cita ignora e estropia de imediato como 'Artamúxia'. Muito a propósito, E. Hall ${ }^{(51)}$ chama a atenção para a insistência no som $\xi$, certamente sentido como bárbaro, em nomes próprios, do persa (Xerxes, Prexaspes) e do cita (Lipoxais, Arpoxais, Araxes). Artamúxia fica a pairar como o símbolo da vitória da esperteza

${ }^{(50)}$ Este era o nome da rainha de Halicarnasso que comandou as forças da sua cidade e ilhas vizinhas, que se juntaram a Xerxes no ataque contra a Grécia (cf. Hdt. 7. 99, 8. 68-69, 8788, 101-103). O seu comportamento masculino na batalha de Salamina terá impressionado até o Grande Rei (Hdt. 8. 88. 3).

(51) 'The archer scene in Aristophanes' Thesmophoriazusae', 40. 
sobre a grosseria e a estupidez. É este o grito de um bárbaro que, ainda uma última vez enganado agora pelas mulheres do coro, corre em todas as direcções em perseguição da misteriosa fugitiva.

Hall ${ }^{(52)}$ vê, na figura do Cita, uma extensão da crítica literária a Eurípides, como criador de peças romanescas, situadas em paisagens exóticas, onde a esperteza do aventureiro grego vive difíceis aventuras de salvação, em desafio com a crueldade do bárbaro (caso de Toas em Ifigénia entre os Tauros, Teoclímeno em Helena e decerto também de Cefeu na Andrómeda). Embora latente, dado o próprio sentido geral da peça e sobretudo das últimas cenas da libertação do prisioneiro, esta relação nunca é explicitada pelo texto. Pelo que, mais do que uma crítica séria aos bárbaros ou uma paródia directa das modernas produções euripidianas, este remate funciona como um aparatoso momento de farsa, que resulta da amplitude de actuação dada à figura de um estúpido.

Algumas conclusões se impõem depois desta análise. Em primeiro lugar, vários indícios apontam no sentido da vulgaridade do recurso ao tipo do bárbaro, entendido como a personagem do estrangeiro, caracterizado por atitudes, costumes e linguagem diversos, que teria na comédia uma presença já antiga e retomada com frequência por diversos comediógrafos. A sua utilização repetida nas peças conservadas de Aristófanes não só comprova a mesma tendência, como permite perceber um esquema fixo, de traços bem estabelecidos, sobre o qual o poeta pode introduzir de cada vez variações, dependendo do contexto e da sua imaginação. Parece claro, em Aristófanes, um progresso no retomar do tema. Talvez mais próximo do modelo popular, enquadrado na realidade política de Atenas, Pseudartabas actua de acordo com um esquema básico, ainda que lhe não falte eficácia. O Tribalo, funcionando dentro de parâmetros semelhantes, adquire uma faceta muito particular, por reproduzir, no Olimpo, os mesmos contrastes de fronteiras existentes na geografia da Grécia. Por fim, o Cita ganha espaço 262 de actuação e uma dimensão mais pessoal. Pela primeira vez deixamos uma certa indefinição do tipo do estrangeiro, para colhermos, na sua actuação, um conjunto de características psicológicas. Com esta evolução passamos de um esquema que sobretudo valoriza contrastes de reacção entre Bárbaros e Gregos, para um outro que se foca mais sobre a personalidade individual do estrangeiro.

(52) 'The archer scene in Aristophanes' Thesmophoriazusae', 4.1. 
É também claro que a uniformidade de tratamento dramático não significa monotonia ou convencionalismo no desenho do bárbaro. A realidade é que cada um deles - o Persa, os Trácios, os Odomantos e Tribalo, o Cita - são exemplares oriundos de paisagens diversas, a que os Gregos associavam comportamentos colectivos próprios. Logo é evidente que, para além das diferenças que os separam da realidade grega, é sugerida uma identidade cultural que os opõe entre si: a riqueza e luxo associam-se a um Persa, o poder físico a um Trácio, uma certa brutalidade e instintos primários a um Cita. Mesmo a linguagem, com todas as dificuldades de leitura que os textos colocam e que muito condiciona a nossa interpretação, parece individualizá-los. Os desvios da norma grega que se evidenciam nos orientais, Persa e Cita, são diferentes dos que caracterizam o Tribalo. Se a prática moderna pode aqui ser de alguma utilidade, não será sensato resumir a questão à ideia de que Aristófanes simplesmente produz uma algaraviada que soe a bárbaro. Pelo contrário, a verdade estará possivelmente mais próxima daquele que seria o procedimento de cada um de nós se quisesse sugerir a forma como estrangeiros, de várias proveniências, usariam a nossa língua. É óbvio que não reduziríamos esta caricatura a um padrão único comum a todos. Penso que, na simplicidade dos exemplos, é essa também a prática de Aristófanes.

De todos estes mecanismos resulta uma figura de efeito seguro, que a comédia não despreza ao longo da sua história, antes retoma e valoriza, em obediência às potencialidades que o tipo oferece, mas também dobrada ao peso da ordem dos tempos, que eram de contactos e queda de barreiras.

\section{Bibliografia}

\section{Edições}

V. Coulon et H. Van Daele - Aristophane, I-V (Paris, reimpr. 19671972).

N. Dunbar - Aristophanes. Birds (Oxford, 1995).

C. E. Graves - Aristophanes. The Acharnians (Cambridge, 1967).

K.Kassel et C. Austin - Poetae Comici Graeci (Berlim, 1983-1989).

TH. Kock - Comicorum Atticorum Fragmenta, I-III (Utrecht, reimpr. 1976).

A. H. Sommerstein - Acharnians (Warminster, 1980). 
A. H. Sommerstein - Birds (Warminster, 1987).

A. H. Sommerstein - Thesmophoriazusae (Warminster, 1994).

Estudos

H. H. BACON - Barbarians in tragedy (New Haven, 1961).

A. C. Cassio - 'Un re di Persia sui monti dell' oro', Eikasmos 2 (1991), 137-141.

K. J. Dover - Aristophanic comedy (Berkeley and Los Angeles, 1972).

L. EDmunds - 'Aristophanes' Acharnians', YClS 26 (1980), 1-41.

E. HALL - Inventing the barbarian. Greek self-definition through tragedy (Oxford, 1989).

E. HALL - 'The archer scene in Aristophanes' Thesmophoriazusae', Philologus 133 (1989), 38-54.

H. Hansen - 'Aristophanes' Thesmophoriazusae: theme, structure and production', Philologus 120 (1976), 165-185.

K. Lever - The art of Greek Comedy (London, 1956).

T. Long - Barbarians in Greek Comedy (Southern Illinois University Press, 1986).

A. López ErRe - La lengua coloquial de la comedia aristofánica (Universidade de Múrcia, 1996).

D. M. MacDowell - Aristophanes and Athens (Oxford, 1995).

A. W. Pickard-CAmbridge - Dithyramb, tragedy and comedy, ed. revised by T. B. L. Webster, (Oxford, ${ }^{2} 1962$ ).

N. W. SLATER - 'Space, character and $\alpha \operatorname{má} T \eta$ : transformation and transvaluation in the Acharnians', in Tragedy, Comedy and the Polis (Bari, 1993) 397-415.

J. Taillardat - Les images d'Aristophane. Études de langue et style (Paris, 1965).

P. Thiercy - Aristophane: fiction et dramaturgie (Paris, 1986).

C. Whitman - Aristophanes and the comic hero (Cambridge, Massachusetts, 1964). 



\section{Série}

\section{Documentos}

Imprensa da Universidade de Coimbra

Coimbra University Press

2005

- U

C - 